\title{
ACTIVITY OF GLUCOSE-FRUCTOSE OXIDOREDUCTASE IN FRESH AND PERMEABILISED CELLS OF ZYMOMONAS MOBILIS GROWN IN DIFFERENT GLUCOSE CONCENTRATIONS
}

\author{
Gilmar Sidnei Erzinger ${ }^{1}$; Mauricio Moura da Silveira ${ }^{2 *}$; José Paulo Castilho Lopes da Costa $^{1}$; Michele Vitolo ${ }^{3}$; \\ Rainer Jonas $^{4}$
}

${ }^{1}$ Universidade da Região de Joinville. Joinville, SC, Brasil. ${ }^{2}$ Instituto de Biotecnologia, Universidade de Caxias do Sul, Caxias do Sul, RS, Brasil. ${ }^{3}$ Faculdade de Ciências Farmacêuticas, Universidade de São Paulo, São Paulo, SP, Brasil. ${ }^{4}$ Gesellschaft für Biotechnologische Forschung mbh, Braunschweig, Germany.

Submitted: January 06 2003; Returned to Authors for corrections: July 24 2003; Approved: September 08, 2003

\begin{abstract}
Previously grown cells of the ethanologenic bacterium Zymomonas mobilis produce sorbitol and gluconic acid, in reactions catalysed by the periplasmic enzymes glucose-fructose oxidoreductase (GFOR) and glucono$\delta$-lactonase (GL). The GFOR/GL system activity, in cells to be used in this bioconversion, depends on growth conditions. In batch runs, with initial glucose concentrations $\left(\mathrm{S}_{0}\right)$ from 42 to $230 \mathrm{~g} / \mathrm{L}$, the highest specific and total GFOR/GL activities were obtained with $S_{0}=153 \mathrm{~g} / \mathrm{L}$ (12.6 U/g cells and $\left.62 \mathrm{U} / \mathrm{L}\right)$. Higher $\mathrm{S}_{0}$ led to decreasing activities in fresh cells. With $\mathrm{S}_{0}=209 \mathrm{~g} / \mathrm{L}$, the final specific activity was only $7.0 \mathrm{U} / \mathrm{g}$. After disruption of cells, however, an activity over $15 \mathrm{U} / \mathrm{g}$ was revealed. Since growth inhibition with $\mathrm{S}_{0}$ over $153 \mathrm{~g} /$ $\mathrm{L}$ was observed in batch mode, fed-batch runs, equivalent to a batch of $230 \mathrm{~g} / \mathrm{L}$, were done. Although no growth inhibition occurred in fed-batch cultivation, enzyme activity remained low $(5.2 \mathrm{U} / \mathrm{g})$. A further fedbatch experiment, carried out under low pressure to remove ethanol from the medium, resulted in a specific activity of $9.8 \mathrm{U} / \mathrm{g}$ and a total activity of $68.7 \mathrm{U} / \mathrm{L}$. These results indicate that the low GFOR/GL activities in $Z$. mobilis cells grown on higher $\mathrm{S}_{0}$ were due to changes in the cell wall, caused by high concentration of ethanol, that hindered the transport of the substrate to the intracellular enzymes in biconversion runs. This conclusion was confirmed by bioconversion runs with cells cultivated under different conditions.
\end{abstract}

Key words: Zymomonas mobilis, glucose-fructose oxidoreductase, glucose.

\section{INTRODUCTION}

Sorbitol is a polyol of increasing interest as sweetener, humectant, texturizer and softener in the food industry. Furthermore, this substance is used for the production of vitamin $\mathrm{C}$, and also sorbose, propylene glycol, synthetic plasticizers and alkyd resins, among other products $(1,10)$. The worldwide production of sorbitol has been estimated to be more than 500,000 Ton per year, having an increasing market (10). The industrial production of sorbitol is traditionally performed by catalytic hydrogenation of $\mathrm{D}$-glucose syrup at a concentration of about 50\% (w/v). In Brazil, sorbitol is produced in a sole industrial plant and a large part of its commercial demand is dependent on importation.
Gluconic acid and its salts are only prepared by the oxidation of glucose (or raw materials that contain glucose). The methods applied can be chemical, electrolytic, catalytic or biotechnological. Nowadays, the latter way is preferred, using Aspergillus niger or Gluconobacter suboxydans as microorganisms. Industrially, gluconic acid and/or its salts are principally used for the removal of zinc coating from metallic objects, the removal of paint and varnish from surfaces, and in the food and pharmaceutical industries as stabiliser (5).

In the presence of both glucose and fructose the ethanologenic bacterium Zymomonas mobilis produces gluconic acid and sorbitol. According to Zachariou and Scopes (11), two enzymes are involved in this bioconversion: glucose-

*Corresponding author: Mailing Address. Instituto de Biotecnologia, Universidade de Caxias do Sul. Caixa Postal 1352. 95001-970, Caxias do Sul, RS, Brasil. Tel.: (+5554) 218-2149. E-mail: mmsilvei@ucs.br. 
fructose oxidoreductase (GFOR) (EC 1.1.99) and glucono- $\delta$ lactonase (GL) (EC 3.1.1.17). GFOR catalyses the reduction of fructose to sorbitol and the oxidation of glucose to glucono- $\delta$ lactone. In the sequence, glucono- $\delta$-lactone is hydrolysed by glucono- $\delta$-lactonase to form gluconic acid. The authors observed that GFOR is preferentially induced by glucose and that the enzyme activity in Z. mobilis extracts was higher when increasing substrate concentration was used for cell growth. The localisation of GFOR in the periplasm of Z. mobilis was later observed by Loos et al. (6) and confirmed by Aldrich et al. (2). Afterwards, Loos et al. (7) described the osmoprotective role of sorbitol for Z. mobilis, suggesting a physiological function of GFOR.

Some processes for producing sorbitol and gluconic acid have been proposed in which, instead of purified enzymes, previously grown, concentrated, and permeabilised Z. mobilis cells were used $(3,8)$. The reason for the permeabilisation of cells was to release essential soluble co-factors needed for the conversion of both glucose and gluconate to ethanol and other catabolic products.

In a previous work, we proposed to use fresh cells of $Z$. mobilis to avoid operational difficulties and reduce costs in large scale production (9). High yields were obtained when the total initial substrate concentration was increased to $600 \mathrm{~g} / \mathrm{L}$, due to the sequential inhibition of the bacterial metabolism by substrates and products, leading to preferential utilisation of substrates via the GFOR/GL system. Since this method requires cell cultivation and enzymes formation for each bioconversion run, the cost for this phase must be compensated for by the ethanol produced. In this context, the aim of this work was to study the formation of GFOR/GL and ethanol by Z. mobilis, with different glucose concentrations, in batch and fed batch modes. The effect of fermentative ethanol on enzymes activity is discussed. Furthermore, the production of gluconic acid and sorbitol with Z. mobilis cells grown under different conditions is evaluated.

\section{MATERIALS AND METHODS}

\section{Micro-organism and Growth Conditions}

Zymomonas mobilis ATCC 29191, used in all experiments, was maintained in liquid medium at $4^{\circ} \mathrm{C}$. The medium used for maintenance, inocula production, and fermentation experiments had the following composition (g/L): glucose, 20 (maintenance), 100 (inoculum), 42 to 230 (batch experiments); $\left(\mathrm{NH}_{4}\right)_{2} \mathrm{SO}_{4}, 1.0$; $\mathrm{MgSO}_{4} .7 \mathrm{H}_{2} \mathrm{O}, 0.5 ; \mathrm{KH}_{2} \mathrm{PO}_{4}, 1.0$; yeast extract, 5.0. Concentrated glucose solutions $(500 \mathrm{~g} / \mathrm{L})$ were prepared and sterilised separately and added to the medium before inoculation. In fedbatch experiments, initial glucose concentration was $150 \mathrm{~g} / \mathrm{L}$, and the feed medium had the same nutrient formulation but a sugar concentration of $500 \mathrm{~g} / \mathrm{L}$. Sterilisation of nutrients and glucose solutions was done at $121^{\circ} \mathrm{C}$ for $20 \mathrm{~min}$.
Fermentation runs were carried out in a Biostat ED bioreactor (B. Braun Biotech, Germany). The temperature was kept at $30^{\circ} \mathrm{C}$, the $\mathrm{pH}$ was controlled at 5.5 with $5 \mathrm{M} \mathrm{NaOH}$, and the impeller speed was $400 \mathrm{rpm}$. Initial volumes in batch and in fed-batch runs were, respectively, 15 and $12 \mathrm{~L}$. In fed batch runs, $3 \mathrm{~L}$ of feed medium, at a flow rate of $0.46 \mathrm{~L} / \mathrm{h}$, were added to the medium when the cell concentration reached ca. 3-4 g/L. Inocula for all runs, corresponding to $10 \%$ of the total volume, were grown under reciprocal agitation for $12 \mathrm{~h}$ at $30^{\circ} \mathrm{C}$.

\section{Bioconversion of Glucose and Fructose to Gluconic Acid and Sorbitol}

Bioconversion of glucose and fructose to sorbitol and gluconic acid was performed in a $500 \mathrm{~mL}$ bioreactor, containing $300 \mathrm{~mL}$ of a solution with $300 \mathrm{~g} / \mathrm{L}$ of each substrate and $30 \mathrm{~g} / \mathrm{L}$ of fresh or permeabilised cells of $Z$. mobilis, under magnetic stirring. The $\mathrm{pH}$ was automatically controlled at 6.4 by adding $10 \mathrm{M} \mathrm{NaOH}$ and the temperature was $39^{\circ} \mathrm{C}$. Cell permeabilisation was done by treating concentrated Z. mobilis suspensions with cetyltrimethylammonium bromide (CTAB) as described by Rehr et al. (8).

\section{Analytical Methods}

Cell concentration was determined by measuring the optical density of cell suspensions at $560 \mathrm{~nm}$. Turbidimetric measurements gave a linear relationship with dry cell mass for each case. In samples from fermentation runs, glucose was assayed enzymatically by using a glucose oxidase / peroxidase test-kit (CELM, Brazil; product number 3863). Ethanol was analysed by gas chromatography (HP model 5890, USA) with a FID detector. GFOR/GL activity was estimated by incubating 2 $\mathrm{g} / \mathrm{L}$ of $Z$. mobilis cells in a solution containing $0.8 \mathrm{M}$ each of glucose and fructose, in a $1 \mathrm{M}$ phosphate/citrate buffer $(\mathrm{pH}$ 6.4), at $39^{\circ} \mathrm{C}$, for $20 \mathrm{~min}$. (4). Alternatively, GFOR/GL activity was measured in cell extracts after disruption in a Retsch (Germany) mill. One unit of enzymatic activity was defined by the production of one gram of gluconic acid per hour under the assay conditions. Gluconic acid determination was done by enzymatic method (Boehringer-Mannheim, Germany; product number E0428191). Samples from bioconversion experiments containing glucose, fructose, and sorbitol were analysed by liquid chromatography (Merck-Hitachi, Germany) with a RI detector, using an Eurokat-Pb column (Knauer, Germany).

\section{RESULTS AND DISCUSSION}

Initially 6 batch runs, with initial glucose concentration $\left(\mathrm{S}_{0}\right)$ from 42 to $230 \mathrm{~g} / \mathrm{L}$, were carried out. The general results are presented in Table 1.

From the values calculated for the cell yield $\left(\mathrm{Y}_{\mathrm{X} / \mathrm{s}}\right)$ and the maximal specific growth rate $\left(\mu_{\mathrm{X}, \mathrm{m}}\right)$ of each run, it is clear that sugar concentrations up to $105 \mathrm{~g} / \mathrm{L}$ have no inhibitory effect on 
cell growth, while $S_{0}=153 \mathrm{~g} / \mathrm{L}$ led to decreasing $\mathrm{Y}_{\mathrm{X} / \mathrm{S}}$ and $\mu_{\mathrm{X}, \mathrm{m}}$. In the extreme case $\left(S_{0}=230 \mathrm{~g} / \mathrm{L}\right)$, the cell yield was less than $40 \%$ of that measured at non inhibitory conditions.

With S0 from 42 to $209 \mathrm{~g} / \mathrm{L}$, similar ethanol yields, between 0.45 and $0.50 \mathrm{~g} / \mathrm{g}$, were calculated (Table 1 ). Since Z. mobilis is an obligate anaerobe, it depends on the formation of ethanol to accomplish its energetic metabolism, and, therefore, would normally convert glucose to ethanol with similar yields. On the other hand, the use of an initial glucose concentration of $230 \mathrm{~g} / \mathrm{L}$ resulted in lower ethanol yield $(0.33 \mathrm{~g} / \mathrm{g})$.

With respect to the specific GFOR/GL activity in Z. mobilis cells, increasing values were measured with $\mathrm{S}_{0}$ up to $153 \mathrm{~g} / \mathrm{L}$. With higher $\mathrm{S}_{0}$ however, the positive effect of increasing glucose concentrations on GFOR activity, reported by Zachariou and Scopes (11), was no longer observed. In fact, with $\mathrm{S}_{0}=209 \mathrm{~g} / \mathrm{L}$, the specific GFOR/GL activity was dramatically reduced (Table 1). Taking into account both the specific activity and the cell mass, the total GFOR/GL activity $(68.7 \mathrm{U} / \mathrm{L})$ achieved with $\mathrm{S}_{0}=$ $153 \mathrm{~g} / \mathrm{L}$ was significantly higher than in any other condition.

Fig. 1 shows the time course for GFOR/GL specific activity in Z. mobilis cells, with $\mathrm{S}_{0}$ of $42,105,153$, and $209 \mathrm{~g} / \mathrm{L}$. As seen, the best activities were measured for the two runs with higher $S_{0}$. In these cases, increasing specific activities were observed in the first 8 hours, approximately, followed by decreasing values of activity for both sugar concentrations. With $\mathrm{S}_{0}=153 \mathrm{~g} / \mathrm{L}$, activity reached its minimum when the substrate was completely depleted and afterwards increased to a value close to the maximum previously measured. With $\mathrm{S}_{0}=209 \mathrm{~g} / \mathrm{L}$, however, the low activity remained constant even after the total consumption of glucose.

To elucidate such behaviour, considering that the positive effect of increasing glucose concentrations on GFOR induction reported in the literature (11) was observed with free enzyme preparations, cells harvested at different times in runs with $\mathrm{S}_{0}=$ 153 and $209 \mathrm{~g} / \mathrm{L}$ were disrupted and the free GFOR/GL activity was determined. As seen in Fig. 2, until 6 to $8 \mathrm{~h}$ of fermentation, similar specific activities were found by both methods. In the sequence, however, free GFOR/GL analysis has shown quite higher activities when compared with the results obtained with non disrupted cells. Since GFOR/GL are periplasmic enzymes, their catalytic action in fresh cells depends on the transport of

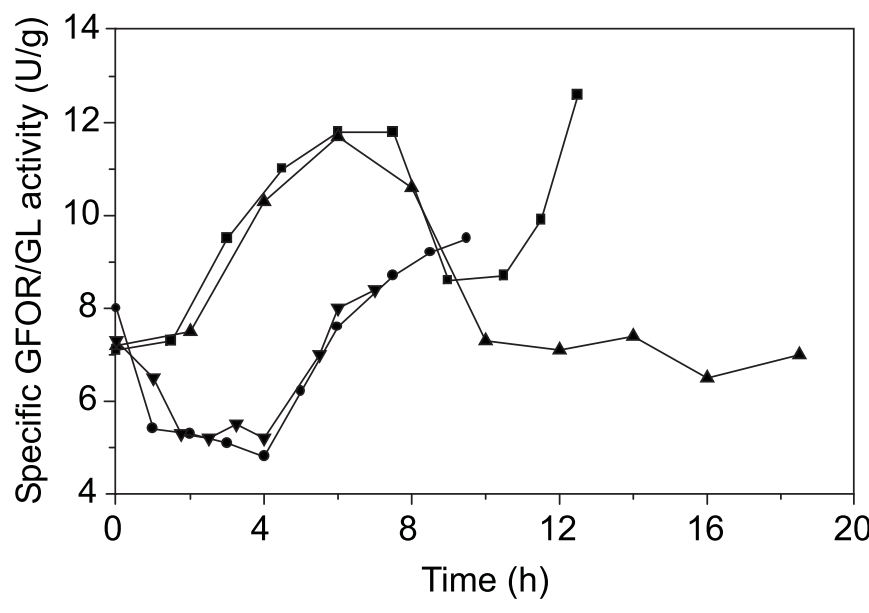

Figure 1. Variation of GFOR/GL specific activity with time in fresh Zymomonas mobilis cells grown, in batch mode, in different initial glucose concentrations. $\nabla \mathrm{S}_{0}=42 \mathrm{~g} / \mathrm{L} ; \mathrm{S}_{0}=105 \mathrm{~g} / \mathrm{L}$; $\square \mathrm{S}_{0}=153 \mathrm{~g} / \mathrm{L} ; \boldsymbol{\Delta} \mathrm{S}_{0}=209 \mathrm{~g} / \mathrm{L}$.

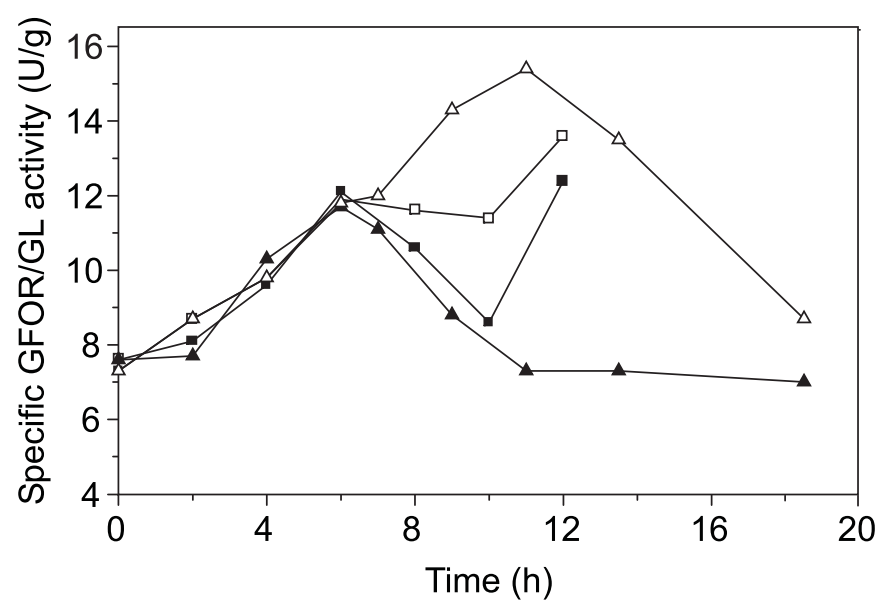

Figure 2. Variation of GFOR/GL specific activity with time in cells of Zymomonas mobilis grown, in batch mode, in $153 \mathrm{~g}$ glucose / L ( $\square$ fresh cells; $\square$ enzyme extract) and 209 g glucose /L ( $\boldsymbol{\Delta}$ fresh cells; $\triangle$ enzyme extract).

Table 1. Batch fermentation of glucose by Zymomonas mobilis ATCC 29191 with different initial glucose concentrations $\left(\mathrm{S}_{0}\right)$.

\begin{tabular}{|c|c|c|c|c|c|c|}
\hline $\begin{array}{c}\mathrm{S}_{0} \\
(\mathrm{~g} / \mathrm{L})\end{array}$ & $\begin{array}{l}\text { Process time } \\
\text { (h) }\end{array}$ & $\begin{array}{l}\text { Cell yield } \\
(\mathrm{g} / \mathrm{g})\end{array}$ & $\begin{array}{l}\text { Ethanol yield } \\
(\mathrm{g} / \mathrm{g})\end{array}$ & $\begin{array}{l}\text { Max. specific } \\
\text { growth rate }\left(\mathrm{h}^{-1}\right)\end{array}$ & $\begin{array}{c}\text { Specific GFOR/GL } \\
\text { activity }(\mathrm{U} / \mathrm{g})\end{array}$ & $\begin{array}{c}\text { Total GFOR/GL } \\
\text { ctivity }(\mathrm{U} / \mathrm{L})\end{array}$ \\
\hline 42 & 6.0 & 0.043 & 0.48 & 0.49 & 8.4 & 17.7 \\
\hline 89 & 6.5 & 0.042 & 0.49 & 0.48 & 9.7 & 36.9 \\
\hline 105 & 8.5 & 0.041 & 0.49 & 0.48 & 9.9 & 39.3 \\
\hline 153 & 10.4 & 0.035 & 0.50 & 0.43 & 12.6 & 62.2 \\
\hline 209 & 16.0 & 0.023 & 0.45 & 0.27 & 7.0 & 36.3 \\
\hline 230 & 42.0 & 0.017 & 0.33 & 0.17 & 3.6 & 15.1 \\
\hline
\end{tabular}


substrates through the cell wall. As such, our results were probably due to some change in the cell wall that partially obstructed the flux of glucose and fructose to the periplasm during the enzymatic assay.

Among the factors that could modify the cells and, consequently, interfere on the substrate/enzyme interaction, ethanol, due to its high concentration in the medium at such conditions, was an obvious first choice for evaluation. For that purpose, an experiment under low pressure $(100 \mathrm{~mm} \mathrm{Hg})$, to extract part of the formed ethanol from the bioreactor, was carried out. Since the attainment of a large product concentration depends, as already shown in this work, on the use of inhibitory $\mathrm{S}_{0}$, that test was done in fed batch mode and compared with a run at identical conditions but under normal pressure. The general results of these experiments are summarised in Table 2. To help the discussion, data of the batch run with $\mathrm{S}_{0}=230 \mathrm{~g} / \mathrm{L}$ are included in Table 2.

By comparing the results of runs in batch and fed batch modes at $760 \mathrm{~mm} \mathrm{Hg}$, one can immediately conclude that fed batch is a suitable way to perform this fermentation, when large amounts of glucose are needed, since it results in improving cell and ethanol yields in a shorter time. The most interesting result, however, was the apparent GFOR/GL specific activity achieved in the run under low pressure, that was almost the double of that measured in the fed batch fermentation under atmospheric pressure (Table 2 and Fig. 3). Considering that the final ethanol concentration was less than $65 \mathrm{~g} / \mathrm{L}$ in the low pressure fermentation, whereas in the normal pressure run ethanol concentration reached $114 \mathrm{~g} / \mathrm{L}$, it is clear that ethanol hindered the action of GFOR/GL in fresh Z. mobilis cells grown on high glucose concentrations. Furthermore, under low pressure the cell yield was approximately $30 \%$ higher. Total GFOR/GL activity was $68.7 \mathrm{U} / \mathrm{L}$, significantly larger than that calculated for the room pressure fed-batch experiment (29.4 U/L).

Cells of Z. mobilis, cultivated under different conditions, were evaluated for the bioproduction of gluconic acid and sorbitol. The general results are shown in Table 3. For the calculation of yields and specific productivities, the dilution of medium, due to the addition of $\mathrm{NaOH}$ solution to control $\mathrm{pH}$, was considered. Similar good results were obtained in runs carried out with fresh cells grown on $150 \mathrm{~g} / \mathrm{L}$ of glucose, in batch mode, or under low pressure in fed batch mode. On the other hand, due to the low specific GFOR/GL activity, the bioconversion experiment with cells from fed-batch cultivation at normal atmospheric pressure presented significantly poorer results. Although such results were expected, this last experiment was done to observe whether the osmotic pressure of the bioconversion medium would be high enough to disrupt the cells, and therefore, facilitate the access of substrates to enzymes.

Furthermore, low-activity cells were permeabilised with CTAB and used in a bioconversion experiment. By this procedure, larger pores were opened in the cell wall to allow an easier access of substrates to GFOR/GL, but the enzymes still remained in cell periplasm (8). As shown in Table 3, with

Table 2. Batch and fed-batch fermentation of glucose by Zymomonas mobilis ATCC 29191 under different pressures $\left(\mathrm{S}_{0}\right)$.

\begin{tabular}{cccccccc}
\hline $\begin{array}{c}\mathrm{S}_{0} \\
(\mathrm{~g} / \mathrm{L})\end{array}$ & $\begin{array}{c}\text { Pressure } \\
(\mathrm{mm} \mathrm{Hg})\end{array}$ & $\begin{array}{c}\text { Process time } \\
(\mathrm{h})\end{array}$ & $\begin{array}{c}\text { Cell yield } \\
(\mathrm{g} / \mathrm{g})\end{array}$ & $\begin{array}{c}\text { Ethanol yield } \\
(\mathrm{g} / \mathrm{g})\end{array}$ & $\begin{array}{c}\text { Max. specific } \\
\text { growth rate }\left(\mathrm{h}^{-1}\right)\end{array}$ & $\begin{array}{c}\text { Specific GFOR/GL } \\
\text { activity }(\mathrm{U} / \mathrm{g})\end{array}$ & $\begin{array}{c}\text { Total GFOR/GL } \\
\text { Activity }(\mathrm{U} / \mathrm{L})\end{array}$ \\
\hline $230^{1}$ & 760 & 42.0 & 0.017 & 0.33 & 0.17 & 3.6 & 15.1 \\
$227^{2,3}$ & 760 & 16.0 & 0.024 & 0.50 & 0.44 & 5.2 & 29.4 \\
$223^{2,3}$ & 100 & 15.0 & 0.030 & - & 0.45 & 9.8 & 68.7 \\
\hline
\end{tabular}

${ }^{1}$ Batch mode; ${ }^{2} \mathrm{Fed}-$ batch mode; ${ }^{3}$ Equivalent glucose concentration (glucose mass/final volume).

Table 3. Bioconversion of glucose and fructose to gluconic acid and sorbitol, respectively, by Zymomonas mobilis cells grown under different conditions (initial glucose + fructose $=600 \mathrm{~g} / \mathrm{L}$ ).

\begin{tabular}{|c|c|c|c|c|}
\hline & \multicolumn{4}{|c|}{ Growth condition } \\
\hline & $\begin{array}{c}\text { Batch } \\
\left(\mathrm{S}_{0}=150 \mathrm{~g} / \mathrm{L}\right)\end{array}$ & $\begin{array}{r}\text { Fed-batch at } \\
100 \mathrm{mmHg}\end{array}$ & $\begin{array}{c}\text { Fed-batch at } \\
760 \mathrm{mmHg}\end{array}$ & $\begin{array}{c}\text { Fed-batch at } 760 \mathrm{mmHg} \\
(\mathrm{CTAB} \text { permeabilised cells })\end{array}$ \\
\hline Process time $(\mathrm{h})$ & 6.0 & 6.0 & 14.0 & 6.5 \\
\hline Gluconic acid (g/L) & 290 & 290 & 240 & 290 \\
\hline Sorbitol (g/L) & 288 & 290 & 233 & 290 \\
\hline Gluconic acid yield ${ }^{1}(\mathrm{~g} / \mathrm{g})$ & 1.07 & 1.04 & 0.89 & 1.04 \\
\hline Sorbitol yield ${ }^{2}(g / g)$ & 0.98 & 0.93 & 0.85 & 0.94 \\
\hline Specific gluconic acid productivity (g/g.h) & 1.78 & 1.67 & 0.62 & 1.52 \\
\hline Specific sorbitol productivity (g/g.h) & 1.64 & 1.64 & 0.61 & 1.43 \\
\hline
\end{tabular}

${ }^{1}$ Maximum theoretical yield $=1.089 \mathrm{~g}$ gluconic acid $/ \mathrm{g}$ glucose $;{ }^{2}$ Maximum theoretical yield $=1.011 \mathrm{~g}$ sorbitol $/ \mathrm{g}$ fructose. 


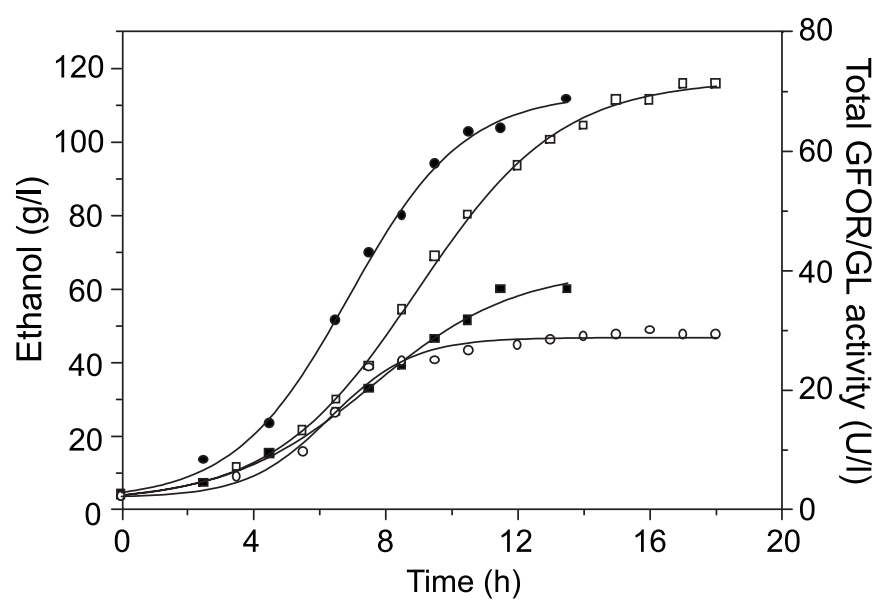

Figure 3. Time course of Zymomonas mobilis cultivation at 760 $\mathrm{mmHg}$ ( $\square$ ethanol; $\bigcirc$ GFOR/GL total activity) and at $100 \mathrm{mmHg}$ ( $\square$ ethanol; GFOR/GL total activity).

permeabilised Z. mobilis high values for both final concentration of products, yields, and specific productivities were achieved, confirming the hypothesis proposed with respect to changes in the cell wall when an excessive substrate concentration is used for cell cultivation.

Although our results have confirmed the findings of Zachariou and Scopes (11), i.e. periplasmic glucose-fructose oxidoreductase activity is improved when Zymomonas mobilis is grown on high glucose concentrations, the catalytic potential of enzymes present in fresh cells is reduced due to the exposition to high levels of ethanol. As such, assuming that fresh cells would be employed for the production of sorbitol and gluconic acid, the Z. mobilis growth step must be carefully optimised.

\section{RESUMO}

\section{Atividade de glicose-frutose oxidorredutase em células íntegras e permeabilizadas de Zymomonas mobilis cultivadas em diferentes concentrações de glicose}

Sorbitol e ácido glucônico são produzidos por células previamente cultivadas da bactéria produtora de etanol Zymomonas mobilis pela ação das enzimas periplasmáticas glicose-frutose oxidorredutase (GFOR) e glucono- $\delta$-lactonase (GL). A atividade de GFOR/GL em células a serem empregadas nesta bioconversão depende das condições de crescimento. Em cultivo em regime descontínuo, com concentrações iniciais de glicose $\left(\mathrm{S}_{0}\right)$ entre 42 e $230 \mathrm{~g} / \mathrm{L}$, as maiores atividades específica e total de GFOR/GL foram obtidas com $\mathrm{S}_{0}=153 \mathrm{~g} / \mathrm{L}(12,6 \mathrm{U} / \mathrm{g}$ de células e $62 \mathrm{U} / \mathrm{L}$ ), enquanto maiores $\mathrm{S}_{0}$ levaram a atividades decrescentes em células não tratadas. Com $\mathrm{S}_{0}=209 \mathrm{~g} / \mathrm{L}$, a atividade específica final foi de $7 \mathrm{U} / \mathrm{g}$, mas, após a ruptura das células, atividade superior a $15 \mathrm{U} / \mathrm{g}$ foi medida. Uma vez que em descontínuo observou-se inibição por substrato com $\mathrm{S}_{0}$ a partir de $153 \mathrm{~g} / \mathrm{L}$, ensaios em regime descontínuo alimentado, com glicose equivalente a $230 \mathrm{~g} / \mathrm{L}$ em descontínuo, foram realizados. Embora a inibição pelo substrato tenha sido superada, a atividade permaneceu baixa $(5,2 \mathrm{U} / \mathrm{g})$. Um novo ensaio em descontínuo alimentado, conduzido sob baixa pressão para remover o etanol do meio, resultou em atividade específica de $9,8 \mathrm{U} / \mathrm{g}$ e total de 68,7 U/L. Estes resultados indicam que as baixas atividades em células de Z. mobilis cultivadas com maiores $\mathrm{S}_{0}$ se deveram a mudanças na parede celular, provocadas por concentrações elevadas de etanol, que dificultaram o transporte de substrato para as enzimas intracelulares durante a bioconversão. Esta conclusão foi confirmada em ensaios de bioconversão com células provenientes de cultivos em diferentes condições.

Palavras-chave: Zymomonas mobilis, glicose-frutose oxidoreductase, glicose.

\section{REFERENCES}

1. Albert, R.; Strätz, A.; Vollheim, G. Die katalytische Herstellung von Zuckeralkoholen und deren Verwendung. Chem. Ing. Tech., 52:582587, 1980.

2. Aldrich, H.C.; McDowell, L.; Barbosa, M.F.S.; Yomano, L.P.; Scopes, R.K.; Ingram, L.O. Immunocytochemical localisation of glucolytic and fermentative enzymes in Zymomonas mobilis. J. Bacteriol., 174:4504-4508, 1992

3. Chun, U.H.; Rogers, P.L. The simultaneous production of sorbitol and gluconic acid by Zymomonas mobilis. Appl. Microbiol. Biotechnol., 29:19-24, 1988.

4. Erzinger, G.S.; Silveira, M.M.; Vitolo, M.; Jonas, R. Determination of glucose-fructose oxidoreductase activity in whole cells of Zymomonas mobilis. World J. Microbiol. Biotechnol., 12:22-24, 1996.

5. Hustede, H.; Haberstroh, H.J.; Schinzig, E. Gluconic acid. In: Ullmann's Encyclopedia of Industrial Chemistry, 6th ed., WileyVCH, Weinheim, 2003, 15:645-653.

6. Loos, H.; Völler, M.; Rehr B.; Stierhof, Y.D.; Sahm, H.; Sprenger, G.A. Localisation of the glucose-fructose oxidoreductase in wild type and overproducing strains of Zymomonas mobilis. FEMS Microbiol. Lett., 84:211-216, 1991.

7. Loos, H.; Krämer, R.; Sahm, H.; Sprenger, G.A. Sorbitol promotes growth of Zymomonas mobilis in environments with high concentrations of sugar: evidence for a physiological function of glucose-fructose oxidoreductase in osmoprotection. J. Bacteriol. 176:7688-7693

8. Rehr, B.; Wilhelm, C.; Sahm, H. Production of sorbitol and gluconic acid by permeabilized cells of Zymomonas mobilis. Appl. Microbiol. Biotechnol., 35:144-148, 1991.

9. Silveira, M.M.; Wisbeck, E.; Lemmel, C.M.; Erzinger, G.S.; Lopes da Costa, J.P.; Bertasso, M.; Jonas, R. Bioconversion of glucose and fructose to sorbitol and gluconic acid by untreated cells of Zymomonas mobilis. J. Biotechnol., 75:99-103, 1999.

10. Vogel, R. Sorbitol. In: Ullmann's Encyclopedia of Industrial Chemistry, $6^{\text {th }}$ ed., Wiley-VCH, Weinheim, 2003, 34:492-498.

11. Zachariou M; Scopes R.K. Glucose-fructose oxidoreductase, a new enzyme isolated from Zymomonas mobilis that is responsible for sorbitol production. J. Bacteriol., 167:803-809. 1986. 